\title{
Fibrinogen metabolic responses to trauma
}

\section{Wenjun Zhou Martini}

\author{
Address: U.S. Army Institute of Surgical Research, Ft. Sam Houston, TX 78234, USA \\ Email: Wenjun Zhou Martini - wenjun.martini@amedd.army.mil
}

\author{
Published: 13 January 2009 \\ Received: 22 November 2008 \\ Scandinavian Journal of Trauma, Resuscitation and Emergency Medicine 2009, 17:2 doi:10.1 I86/1757-724I-17- Accepted: 13 January 2009
}

2

This article is available from: http://www.sjtrem.com/content/I7/I/2

(c) 2009 Martini; licensee BioMed Central Ltd.

This is an Open Access article distributed under the terms of the Creative Commons Attribution License (http://creativecommons.org/licenses/by/2.0), which permits unrestricted use, distribution, and reproduction in any medium, provided the original work is properly cited.

\begin{abstract}
Coagulation complications are significant contributors to morbidity and mortality in trauma patients. Although the lethal triad of hypothermia, acidosis and coagulopathy has been recognized for over a decade, the underlying mechanisms related to the development of coagulopathy remain unclear. Recent data suggest that decreased fibrinogen levels contribute to the development of coagulation disorders. Thus, regulation of fibrinogen availability, not fully understood at present, may play an important role in survival of trauma patients. This review summarizes the recent findings of the studies that have explored mechanisms related to changes in fibrinogen availability following trauma-related events. Trauma alters fibrinogen metabolism in a variety of ways: hemorrhage - accelerated fibrinogen breakdown; hypothermia - inhibited fibrinogen synthesis; and, acidosis - accelerated fibrinogen breakdown. However, hemorrhage, hypothermia andcidosis all result in a consistent outcome of fibrinogen availability deficit, supporting the notion of fibrinogen supplementation in trauma patients with coagulation defects. Future prospective clinical trials are needed to confirm the beneficial effects of fibrinogen supplementation in trauma patients with bleeding complications.
\end{abstract}

\section{Introduction}

Coagulation complications are significant contributors to morbidity and mortality in trauma patients $[1,2]$. Mortality in patients with severe injuries and coagulopathy is found to be four times greater than in patients with injuries alone [3]. Trauma-related coagulopathy is associated with hypoperfusion due to tissue injury and blood loss, hemodilution from resuscitation with crystalloid and/or colloid solutions, progressive hypothermia and the development of acidosis. Since the recognition of the lethal triad of hypothermia, acidosis, and coagulopathy over a decade ago $[1,2]$, a great deal of effort has been made to elucidate possible mechanisms contributing to trauma related coagulopathy as well as to search for effective treatments [4-7]. Recent data suggest that fibrinogen availability may play an important role in the survival of patients.
The purpose of this article is to review recent findings that have been made concerning clotting protein fibrinogen metabolism and availability following trauma-related events, including hemorrhage, resuscitation, hypothermia and acidosis.

\section{Fibrinogen Availability}

As the precursor of clot formation, fibrinogen plays an important role in coagulation function. Fibrinogen deficiency is associated with uncontrolled bleeding and compromised survival [8-12]. Thus, regulation of fibrinogen availability is critical to survival in trauma patients.

As an acute phase protein, fibrinogen is synthesized in the liver and released into the circulation. It is catabolized through normal protein degradation, the coagulation 
process, and other unknown pathways. At any moment, fibrinogen availability is delineated by the dynamic balance of synthesis and breakdown. Mathematically, fibrinogen availability can be expressed as:

Fibrinogen availability $=[$ [Fibrinogen $] \times$ total plasma volume + [synthesis rate $\times$ time $]-$ [breakdown rate $\times$ time]

Where [fibrinogen] is the initial fibrinogen concentration $(\mathrm{mg} / \mathrm{dL})$; synthesis is the amount of fibrinogen (mg) produced in a unit of time (hour); and breakdown rate is the amount of fibrinogen ( $\mathrm{mg}$ ) consumed in a unit of time (hour).

The importance of initial fibrinogen concentration is demonstrated by its relationship to maximum allowable blood loss before casualties reach critical status. Using a mathematical model to analyze hemostasis during blood loss that was validated with clinical data collected from 208 consecutive patients, Singbartl et al. showed that the maximal allowable blood loss is highly dependent on the initial fibrinogen levels [13]. For instance, for a given hematocrit (e.g., 45\%) and platelet count (e.g., $225 \times 10^{3} /$ $\mu \mathrm{L})$, when three representative initial fibrinogen levels are $450 \mathrm{mg} / \mathrm{dL}, 300 \mathrm{mg} / \mathrm{dL}$, and $200 \mathrm{mg} / \mathrm{dL}$, the respective maximum allowable blood losses are $3750 \mathrm{ml}, 1900 \mathrm{ml}$, and $750 \mathrm{ml}$, before critical levels of fibrinogen are reached. Although the exact critical levels of fibrinogen at which bleeding complications are provoked are debatable, the point is that bleeding complications do not always happen after large amounts of blood loss and hemodilution. Patients with low initial fibrinogen levels may possibly develop bleeding complications following even moderate blood loss and hemodilution. These patients may also have other pathological conditions present that could contribute to the development of coagulopathy $[4,5,14-16]$.

Fibrinogen concentration is routinely measured by clinical laboratories. In contrast, quantification of fibrinogen synthesis and breakdown presents technical challenges. Consequently, fibrinogen concentration has been the only measurement available to assess changes in fibrinogen. It is worth clarifying that fibrinogen concentration does not in and of itself reveal any information about synthesis or breakdown. For instance, an increased fibrinogen concentration may be due to decreased consumption, and/or increased production, or simply deceases in plasma volume. Thus, to fully understand changes in fibrinogen availability requires information of fibrinogen metabolism.

\section{Quantification of Fibrinogen Metabolism}

The important role of fibrinogen in coagulation led to investigations to study fibrinogen kinetics. In the 1960s and 1970s, fibrinogen synthesis was quantified using radioactive isotope labeled amino acids in experimental animals [17-19]. Upon administration, radioactive labeled amino acids were incorporated into fibrinogen molecules and the increased radioactivities in fibrinogen over time were used to reflect fibrinogen production. By comparing the radioactivities in fibrinogen with the control group, this approach allowed assessment of changes in fibrinogen production, but did not offer any information about fibrinogen breakdown. To measure fibrinogen catabolism, others used radioactive labeled fibrinogen to investigate fibrinogen breakdown in experimental animals and humans [20-25]. In this approach, radioactive labeled fibrinogen (i.e., ${ }^{125}$ I - fibrinogen) was injected into subjects and blood samples were withdrawn daily for 5 to 14 days afterwards. Fibrinogen was then isolated from the blood samples and its radioactivities were measured. The decreases of radioactivities of fibrinogen over time were used to reflect fibrinogen breakdown. This approach was used in the past as an in vivo means to assess changes of fibrinogen breakdown under different pathophysiological states [20-25]. Unfortunately, this approach did not allow quantification of fibrinogen synthesis. Consequently, changes in fibrinogen metabolism remained unclear due to the lack of a methodology to quantify fibrinogen synthesis and breakdown.

Recently, Martini et al. developed an in vivo methodology to quantify fibrinogen synthesis and breakdown rates simultaneously and independently [26]. The simultaneous and independent quantification of synthesis and breakdown provides comprehensive and complete assessment of fibrinogen metabolism and availability. This methodology involves the infusion of stable isotope labeled amino acids with subsequent gas chromatography mass spectrometry analysis. With the infusion of differently labeled amino acids for different durations, the incorporation of the isotopic labels in fibrinogen over time is used to calculate fibrinogen synthesis, while the decay of the isotopic labels in fibrinogen after the infusion ceases is used to calculate fibrinogen breakdown. There are several advantages to this methodology. First, stable isotopes are naturally occurring and safe for use in humans; second, synthesis and breakdown rates are quantified simultaneously and independently in the same subject; and third, the entire study (infusion and blood samplings) takes only 6 to 8 hours, compared to the days required in previous approaches. The establishment of this methodology made it possible to investigate changes of fibrinogen metabolism in trauma.

\section{Effects of Hemorrhage}

Hemorrhage is the leading potentially preventable cause of death on the battlefield and a major cause of death in civilian trauma $[11,27]$. One of the most detrimental 
complications following hemorrhage is the disruption of hemostasis, resulting in uncontrolled bleeding, disseminated intravascular coagulation (DIC), and thrombotic complications $[8,10-12]$. Based on the limited data available at present, changes in fibrinogen availability are involved in the development of clotting disorders. In acutely injured trauma victims, fibrinogen levels were observed to be the first coagulation proteins and factors to drop to pathophysiological levels [8,9], although this is not a universal finding [28]. The observed decrease of fibrinogen was not found to be attributable to blood loss or resuscitation $[8,9]$.

To investigate the effects of hemorrhage on fibrinogen metabolism, a swine model was used in which a moderate hemorrhage was induced by withdrawing $35 \%$ of estimated total blood volume from the femoral artery [26]. After hemorrhage and stabilization, a stable isotope infusion was performed with $1-{ }^{13} \mathrm{C}$ - phenylalanine for 6 hours and $\mathrm{d}_{5}$-phenylalanine for 4 hours. During the infusion, blood samples were collected hourly and isotopic enrichments of fibrinogen from the infusion were determined using gas chromatography mass spectrometry analysis. Data from this study showed that after moderate hemorrhage, fibrinogen breakdown was accelerated compared with the control group. There was no change in the fibrinogen synthesis rate (Additional file 1) [26]. The deficit between fibrinogen production and consumption indicates a potential decrease in fibrinogen availability after hemorrhage. It is worth mentioning that there were no changes in $\mathrm{pH}$ or temperature associated with the $35 \%$ blood loss in this study, suggesting that the effects observed in the study were due to hemorrhage only. Under more severe hemorrhagic shock, changes of fibrinogen metabolism may be different due to possible changes in $\mathrm{pH}$ or temperature resulted from severe blood loss and compromised tissue perfusion.

\section{Effects of lactated Ringer's Resuscitation}

To treat hemorrhagic shock, fluid resuscitation is routinely used in clinical practice to restore tissue perfusion. The effects of various crystalloids and colloids with different volume-expanding capacities have been reported in the literature [29-33]. Among these fluids, lactated Ringers solution (LR) is considered part of standard care [34]. The effects of LR on fibrinogen kinetics were reported recently by Martini et al. in a study of swine [35]. In the study, a moderate hemorrhage was induced by withdrawing 35\% of estimated blood volume in 12 pigs, with an additional 6 pigs used as controls. Afterwards, the 12 hemorrhaged pigs were randomly divided into the hemorrhage only group and hemorrhage-LR resuscitation group. In the hemorrhage-LR resuscitation group, LR solution at 3 times the bled volume was given to the pigs while no fluid was given in the hemorrhage only group. Upon stabilization, stable isotope infusion was performed in all three groups, followed by blood drawn hourly and subsequent gas chromatography mass spectrometry analysis. Data from this study [35] showed that compared with the control value $(3.0 \pm 0.5 \mathrm{mg} / \mathrm{kg} / \mathrm{h})$, fibrinogen breakdown was similarly increased in both the hemorrhage only group $(5.4 \pm 0.7 \mathrm{mg} / \mathrm{kg} / \mathrm{h})$ and the hemorrhage-LR resuscitation group $(5.6 \pm 0.5 \mathrm{mg} / \mathrm{kg} / \mathrm{h})$. There were no significant differences in fibrinogen synthesis among the control group $(2.5 \pm 0.6 \mathrm{mg} / \mathrm{kg} / \mathrm{h})$, the hemorrhage only group $(1.7 \pm 0.3 \mathrm{mg} / \mathrm{kg} / \mathrm{h})$ or the hemorrhage-LR resuscitation group $(2.6 \pm 0.4 \mathrm{mg} / \mathrm{kg} / \mathrm{h}$, Additional file 1$)$. This suggests that the changes in fibrinogen metabolism resulted from hemorrhagic shock and that LR resuscitation itself did not affect fibrinogen metabolism. However, the effects of other resuscitation fluids, such as colloids, on fibrinogen metabolism remain to be investigated.

\section{Effects of Hypothermia}

Hypothermia, clinically defined as a body temperature of $34^{\circ} \mathrm{C}$ or less, is commonly observed in severely injured trauma patients [36]. The association of hypothermia to coagulation dysfunction and mortality has been well described [36-41]. Compared with patients who had a body temperature of $36.1 \pm 0.7^{\circ} \mathrm{C}$, there was a 2.4 -fold increase in blood loss in post-laparotomy patients whose body temperature was $33.8 \pm 0.5^{\circ} \mathrm{C}$ [37]. In a group of trauma patients with Injury Severity Scores (ISS) greater than 25 , the mortality increased from $10 \%$ to $100 \%$ when body temperature declined from $35^{\circ} \mathrm{C}$ to less than $32^{\circ} \mathrm{C}$ [40]. Among nonsurviving trauma patients, approximately $80 \%$ have body temperatures of less than $34^{\circ} \mathrm{C}$ at the time of death [38]. The adverse effects of hypothermia on coagulation have been indicated by prolonged prothrombin time (PT) and activated partial thromboplastin time (aPTT) in hypothermic patients and experimental animals, as well as in plasma samples cooled in vitro [4247]. The dynamic changes of fibrinogen metabolism during hypothermia were revealed recently by Martini et al [48].

In a normovolemic swine model, hypothermia of $32^{\circ} \mathrm{C}$ was induced using a cold blanket with circulating water at $4^{\circ} \mathrm{C}$ [48]. Temperature of $32^{\circ} \mathrm{C}$ was used based on the fact that $100 \%$ mortality was observed when the temperature in trauma patients dropped below $32^{\circ} \mathrm{C}$ [40]. When the animal temperature was lowered to $32^{\circ} \mathrm{C}$ and stabilized, stable isotope $1^{13} \mathrm{C}$-phenylalanine was infused for 6 hours and $d_{5}$-phenylalanine was infused for 4 hours. Blood samples were taken hourly during the infusion and the isotopic labeling of fibrinogen was determined using gas chromatography and mass spectrometry analysis. It was found that hypothermia decreased fibrinogen synthesis, with no effects on fibrinogen breakdown (Additional file 1) [48]. This observation indicates that, in response to 
cooling, fibrinogen synthesis and degradation are regulated via different mechanisms and that there is a potential deficit in fibrinogen availability following hypothermia. The metabolic changes in fibrinogen were associated with prolonged clotting initiation time and decreased clotting speed.

\section{Effects of Acidosis}

Among all the factors contributing to coagulation disorders, acidosis is one of the most important predictors of coagulopathy in trauma patients [49], with the likelihood of death increasing as the severity of acidosis increases [1,38,50-52]. The detrimental effects of acidosis on coagulation include impaired enzyme activities, depleted fibrinogen levels and platelet counts, prolonged clotting times, and increased bleeding times [1,38,50-53]. The mechanisms contributing to the depletions of fibrinogen were reported recently by Martini et al [48].

In a swine model, acidosis of $\mathrm{pH} 7.1$ was induced by an infusion of $0.2 \mathrm{~N} \mathrm{HCl}$ in LR [54]. When the target pH of 7.1 was achieved and stabilized, a stable isotope infusion of $1-{ }^{13} \mathrm{C}$-phenylalanine and $\mathrm{d}_{5}$-phenylalanine was performed with hourly blood sampling. Following gas chromatograph and mass spectrometry analysis, data from this study showed that, in contrast to the effects of hypothermia, acidosis increased fibrinogen breakdown by 1.8 -fold compared with control values, with no effects on fibrinogen synthesis (Additional file 1) [54]. Thus, it appears that there were differential effects on fibrinogen synthesis and breakdown by acidosis and there was a potential depletion of fibrinogen availability following acidosis.

\section{Fibrinogen Supplementation}

Despite the differential effects on fibrinogen synthesis and breakdown, hemorrhage, hypothermia and acidosis all resulted in a single outcome: a deficit in fibrinogen availability. Beneficial effects of fibrinogen supplementation were reported in animal and in vitro studies following the administration of Haemocomplettan $\mathrm{P}^{\circledR}$, a fibrinogen concentrate available in European countries [55-60] (some of these studies were conducted or sponsored by the manufacture). In pigs with $60 \%$ blood volume exchanged with hydroxyethyl starch, Fries et al. investigated the effects of Haemocomplettan $\mathrm{P}^{\circledR}$ together with prothrombin complex concentrate on blood loss from a standard liver laceration and survival [55]. The blood loss in the supplement group was $240 \mathrm{ml}(50-830 \mathrm{ml})$ compared to $1800 \mathrm{ml}$ $(1500-2500 \mathrm{ml})$ in the placebo group. All animals in the supplement group survived compared to $20 \%$ survival in the placebo group [55]. Similarly, in a rat model with sepsis-induced DIC, Kaspereit et al. reported significant decrease in mortality following treatment with Haemocomplettan $\mathrm{P}^{\circledR}$ [58]. Thus, fibrinogen supplementation may be potentially beneficial following massive blood loss and DIC. It remains unclear, however, how early fibrinogen supplementation affects the dynamic features of fibrinogen metabolism.

Consistent with animal studies, decreased fibrinogen levels have been documented in coagulopathic patients [6163]. In search for effective treatments, efforts have been made to evaluate outcomes from transfusion of blood products, such as fresh whole blood, fresh frozen plasma (FFP), cryoprecipitate, and red blood cells (RBC). Recent published retrospective studies suggested potential benefits of transfusion of a higher ratio of fibrinogen to red blood cell unit ratio in trauma patients [6,7,64-72].

To observe the effects of fibrinogen supplementation on survival, Stinger et al. performed a retrospective study in massively transfused trauma patients at a US Army combat support hospital [72]. Two hundred fifty-two trauma patients with an average ISS of $21 \pm 10$ who received 10 or more units of RBC in 24 hours were included in the study. The amount of fibrinogen transfused was calculated based on fibrinogen amount within each blood product, such as fresh whole blood, cryoprecipitate, aphaeresis platelets and FFP. The ratio of fibrinogen-to-RBC was used to identify two patient groups: a low ratio group (ratio $<0.2 \mathrm{~g}$ fibrinogen per RBC unit) and a high ratio group (ratio $\geq 0.2 \mathrm{~g}$ fibrinogen per RBC unit). The authors reported mortality rates of $52 \%$ and $24 \%$ in the low and high ratio groups, respectively $(\mathrm{p}<0.001)$. Upon logistic regression analysis, the fibrinogen-to-RBC ratio was found to be independently associated with mortality [72]. It should be mentioned, however, that some recent studies have called into question the value of high fibrinogen-to-RBC ratio in treatment of trauma patients $[73,74]$. Future prospective clinical trials are needed to clarify the effects of a higher ratio of fibrinogen to $\mathrm{RBC}$ transfusion and outcome in trauma patients.

\section{Conclusion}

Fibrinogen availability is regulated through synthesis and breakdown to maintain coagulation function. Recent studies have revealed the mechanisms underlying changes in fibrinogen availability following trauma. Hemorrhage, hypothermia and acidosis alter fibrinogen metabolism in a variety of ways: First, moderate hemorrhage accelerated fibrinogen breakdown with no significant effects on fibrinogen. Second, hypothermia of $32^{\circ} \mathrm{C}$ inhibited fibrinogen synthesis with no effects on fibrinogen breakdown. Finally, acidosis of pH 7.1 accelerated fibrinogen breakdown without changing fibrinogen synthesis. Despite the differential effects on fibrinogen synthesis and breakdown, hemorrhage, hypothermia and acidosis all lead to a deficit in fibrinogen availability. Recent retrospective clinical studies in trauma patients and animal trials suggest that fibrinogen supplementation may be 
beneficial. Further prospective clinical trials to confirm the benefits of fibrinogen supplementation in trauma patients are warranted.

\section{Abbreviations}

DIC: disseminated intravascular coagulation; LR: lactated Ringer's solution; ISS: Injury Severity Scores; PT: prothrombin time; aPTT: activated partial thromboplastin time; FFP: fresh frozen plasma; RBC: red blood cells.

\section{Competing interests}

The author declares that the author has no competing interests.

\section{Authors' contributions}

The author drafted the manuscript.

\section{Additional material}

\section{Additional file 1}

The effects of hemorrhage, LR resuscitation, hypothermia, and acidosis on fibrinogen synthesis and breakdown in pigs. Data presented were collected during studies conducted by Martini et al $[26,35,48,54] .{ }^{*} p<$ 0.05 compare with control values.

Click here for file

[http://www.biomedcentral.com/content/supplementary/17577241-17-2-S1.jpeg]

\section{Acknowledgements}

This work was supported by the US Army Medical Research and Medical Command.

The opinions or assertions contained herein are the private views of the author and are not to be construed as official or as reflecting the views of the Department of the Army or the Department of Defense.

\section{References}

I. Moore EE: Thomas G. Orr Memorial Lecture. Staged laparotomy for the hypothermia, acidosis, and coagulopathy syndrome. Am J Surg 1996, I72:405-4I0.

2. Rotondo MF, Zonies DH: The damage control sequence and underlying logic. Surg Clin North Am 1997, 77:76I-777.

3. Brohi K, Singh J, Heron M, Coats T: Acute traumatic coagulopathy. J Trauma 2003, 54: I I27-II30.

4. Brohi K, Cohen MJ, Ganter MT, Schultz MJ, Levi M, Mackersie RC, Pittet JF: Acute coagulopathy of trauma: hypoperfusion induces systemic anticoagulation and hyperfibrinolysis. J Trauma 2008 , 64: $1211-1217$

5. Hess JR, Brohi K, Dutton RP, Hauser CJ, Holcomb JB, Kluger Y, Mack way-Jones K, Parr MJ, Rizoli SB, Yukioka T, et al.: The coagulopathy of trauma: a review of mechanisms. ITrauma 2008, 65:748-754

6. Maegele M, Lefering R, Paffrath T, Tjardes T, Simanski C, Bouillon B. Red-blood-cell to plasma ratios transfused during massive transfusion are associated with mortality in severe multiple injury: a retrospective analysis from the Trauma Registry of the Deutsche Gesellschaft fur Unfallchirurgie. Vox Sang 2008, 95: II2-II9.

7. Spinella PC: Warm fresh whole blood transfusion for severe hemorrhage: U.S. military and potential civilian applications. Crit Care Med 2008, 36:S340-345.
8. Armand R, Hess JR: Treating coagulopathy in trauma patients. Transfus Med Rev 2003, 17:223-23I.

9. Collins JA: The pathophysiology of hemorrhagic shock. Prog Clin Biol Res 1982, 108:5-29.

10. Hardy JF, De Moerloose P, Samama M: Massive transfusion and coagulopathy: pathophysiology and implications for clinical management. Can J Anaesth 2004, 5 I:293-3I 0.

11. Sherman LA: DIC in massive transfusion. Prog Clin Biol Res 1982, 108:17|-189.

12. Sherry S: Hemostatic mechanisms and proteolysis in shock. Fed Proc 1961, 20:209-2 I8.

13. Singbartl K, Innerhofer P, Radvan J, Westphalen B, Fries D, Stogbauer $\mathrm{R}$, Van Aken $\mathrm{H}$ : Hemostasis and hemodilution: a quantitative mathematical guide for clinical practice. Anesth Analg 2003, 96:929-935.

14. Brohi K, Cohen MJ, Davenport RA: Acute coagulopathy of trauma: mechanism, identification and effect. Curr Opin Crit Care 2007, 13:680-685.

15. Brohi K, Cohen MJ, Ganter MT, Matthay MA, Mackersie RC, Pittet JF: Acute traumatic coagulopathy: initiated by hypoperfusion: modulated through the protein C pathway? Ann Surg 2007, 245:8|2-8|8.

16. Cohen MJ, Brohi K, Ganter MT, Manley GT, Mackersie RC, Pittet JF: Early coagulopathy after traumatic brain injury: the role of hypoperfusion and the protein C pathway. J Trauma 2007, 63: $1254-1261$.

17. Alving BM, Bell WR, Evatt BL: Fibrinogen synthesis in rabbits: effects of altered levels of circulating fibrinogen. Am J Physio 1977, 232:H478-484.

18. Atencio AC, Burdick DC, Reeve EB: An accurate isotope dilution method for measuring plasma fibrinogen. J Lab Clin Med 1965, 66:137-145.

19. Koj $A$ : The measurement of absolute and relative synthesis rates of fibrinogen in vivo. Biochim Biophys Acta 1968, 165:97-107.

20. Blaisdell FW, Graziano CJ: Assessment of clotting by the determination of fibrinogen catabolism. Am J Surg 1978 135:436-442.

21. Blaisdell FW, Graziano CJ, Effeney DJ: In vivo assessment of anticoagulation. Surgery 1977, 82:827-839.

22. Regoeczi E: Fibrinogen catabolism: kinetics of catabolism following sudden elevation of the pool with exogenous fibrinogen. Clin Sci 1970, 38: I II-I2I.

23. Srichaikul T, Nimmanitaya S, Artchararit N, Siriasawakul T, Sungpeuk $\mathrm{P}$ : Fibrinogen metabolism and disseminated intravascular coagulation in dengue hemorrhagic fever. Am J Trop Med Hyg 1977, 26:525-532

24. Tytgat GN, Collen D, Vermylen J: Metabolism and distribution of fibrinogen. Il. Fibrinogen turnover in polycythaemia, thrombocytosis, haemophilia $A$, congenital afibrinogenaemia and during streptokinase therapy. Br J Haematol 1972, 22:70I-7I7.

25. Tytgat GN, Collen D, Verstraete M: Metabolism of fibrinogen in cirrhosis of the liver. South Med J 1971, 64:1690-I70I.

26. Martini WZ, Chinkes DL, Pusateri AE, Holcomb JB, Yu YM, Zhang XJ, Wolfe RR: Acute changes in fibrinogen metabolism and coagulation after hemorrhage in pigs. Am J Physiol Endocrinol Metab 2005, 289:E930-934.

27. Bellamy RF: The causes of death in conventional land warfare: implications for combat casualty care research. Mil Med I 984 , 149:55-62.

28. Simmons RL, Collins JA, Heisterkamp CA, Mills DE, Andren R, Phillips LL: Coagulation disorders in combat casualties. I. Acute changes after wounding. II. Effects of massive transfusion. 3. Post-resuscitative changes. Ann Surg 1969, 169:455-482.

29. Dries DJ: Hypotensive resuscitation. Shock 1996, 6:3 | I-316.

30. Goodwin CW, Dorethy J, Lam V, Pruitt BA Jr: Randomized trial of efficacy of crystalloid and colloid resuscitation on hemodynamic response and lung water following thermal injury. Ann Surg 1983, 197:520-531.

31. O'Benar JD, Bruttig SP, Wade CE, Dubick MA: Hemodynamic and metabolic responses to repeated hemorrhage and resuscitation with hypertonic saline dextran in conscious swine. Shock 1998, 10:223-228.

32. Traverso LW, Hollenbach SJ, Bolin RB, Langford MJ, DeGuzman LR: Fluid resuscitation after an otherwise fatal hemorrhage: II. Colloid solutions. J Trauma 1986, 26:176-182. 
33. Traverso LW, Lee WP, Langford MJ: Fluid resuscitation after an otherwise fatal hemorrhage: I. Crystalloid solutions. J Trauma 1986, 26: 168-175.

34. Healey MA, Davis RE, Liu FC, Loomis WH, Hoyt DB: Lactated ringer's is superior to normal saline in a model of massive hemorrhage and resuscitation. J Trauma 1998, 45:894-899.

35. Martini WZ, Chinkes DL, Sondeen J, Dubick MA: Effects of hemorrhage and lactated Ringer's resuscitation on coagulation and fibrinogen metabolism in swine. Shock 2006, 26:396-40I.

36. Luna GK, Maier RV, Pavlin EG, Anardi D, Copass MK, Oreskovich $M R$ : Incidence and effect of hypothermia in seriously injured patients. J Trauma 1987, 27:1014-1018.

37. Bernabei AF, Levison MA, Bender JS: The effects of hypothermia and injury severity on blood loss during trauma laparotomy. J Trauma 1992, 33:835-839.

38. Ferrara A, MacArthur JD, Wright HK, Modlin IM, McMillen MA: Hypothermia and acidosis worsen coagulopathy in the patient requiring massive transfusion. Am J Surg 1990, 160:515-518.

39. Gregory JS, Flancbaum L, Townsend MC, Cloutier CT, Jonasson O Incidence and timing of hypothermia in trauma patients undergoing operations. J Trauma 1991, 31:795-798.

40. Jurkovich G], Greiser WB, Luterman A, Curreri PW: Hypothermia in trauma victims: an ominous predictor of survival. J Trauma 1987, 27:1019-1024.

4I. Steinemann S, Shackford SR, Davis JW: Implications of admission hypothermia in trauma patients. J Trauma 1990, 30:200-202.

42. Kermode JC, Zheng Q, Milner EP: Marked temperature dependence of the platelet calcium signal induced by human von Willebrand factor. Blood 1999, 94:199-207.

43. Kurrek MM: Effect of hypothermia on enzymatic activity of thrombin and plasmin. Surg Forum 1987, 38:22I-223.

44. Reed RL 2nd, Johnson TD, Hudson JD, Fischer RP: The disparity between hypothermic coagulopathy and clotting studies. Trauma 1992, 33:465-470.

45. Rohrer MJ, Natale AM: Effect of hypothermia on the coagulation cascade. Crit Care Med 1992, 20:1402-1405.

46. Staab DB, Sorensen VJ, Fath J], Raman SB, Horst HM, Obeid FN: Coagulation defects resulting from ambient temperatureinduced hypothermia. J Trauma 1994, 36:634-638.

47. Watts DD, Trask A, Soeken K, Perdue P, Dols S, Kaufmann C: Hypothermic coagulopathy in trauma: effect of varying levels of hypothermia on enzyme speed, platelet function, and fibrinolytic activity. J Trauma 1998, 44:846-854.

48. Martini WZ: The effects of hypothermia on fibrinogen metabolism and coagulation function in swine. Metabolism 2007, 56:2I4-22I.

49. Cosgriff N, Moore EE, Sauaia A, Kenny-Moynihan M, Burch JM, Galloway $B$ : Predicting life-threatening coagulopathy in the massively transfused trauma patient: hypothermia and acidoses revisited. J Trauma 1997, 42:857-86I.

50. Lynn M, Jeroukhimov I, Klein Y, Martinowitz U: Updates in the management of severe coagulopathy in trauma patients. Intensive Care Med 2002, 28(Suppl 2):S24I-247.

51. Mikhail J: The trauma triad of death: hypothermia, acidosis, and coagulopathy. AACN Clin Issues 1999, 10:85-94.

52. Moore FA, McKinley BA, Moore EE: The next generation in shock resuscitation. Lancet 2004, 363:1988-1996.

53. Martini WZ, Pusateri AE, Uscilowicz JM, Delgado AV, Holcomb JB Independent contributions of hypothermia and acidosis to coagulopathy in swine. J Trauma 2005, 58:1002-1009.

54. Martini WZ, Holcomb JB: Acidosis and coagulopathy: the differential effects on fibrinogen synthesis and breakdown in pigs. Ann Surg 2007, 246:83I-835.

55. Fries D, Haas T, Klingler A, Streif W, Klima G, Martini J, WagnerBerger $\mathrm{H}$, Innerhofer P: Efficacy of fibrinogen and prothrombin complex concentrate used to reverse dilutional coagulopathy - a porcine model. BrJ Anaesth 2006, 97:460-467.

56. Fries D, Innerhofer $P$, Reif $C$, Streif $W$, Klingler A, Schobersberger W, Velik-Salchner C, Friesenecker B: The effect of fibrinogen substitution on reversal of dilutional coagulopathy: an in vitro model. Anesth Analg 2006, 102:347-35I.

57. Haas T, Fries D, Velik-Salchner C, Reif C, Klingler A, Innerhofer P: The in vitro effects of fibrinogen concentrate, factor XIII and fresh frozen plasma on impaired clot formation after $\mathbf{6 0 \%}$ dilution. Anesth Analg 2008, 106:1360-1365.
58. Kaspereit F, Doerr B, Dickneite G: The effect of fibrinogen concentrate administration on coagulation abnormalities in a rat sepsis model. Blood Coagul Fibrinolysis 2004, I5:39-43.

59. Mittermayr M, Streif W, Haas T, Fries D, Velik-Salchner C, Klingler A Oswald E, Bach C, Schnapka-Koepf M, Innerhofer P: Hemostatic changes after crystalloid or colloid fluid administration during major orthopedic surgery: the role of fibrinogen administration. Anesth Analg 2007, 105:905-917.

60. Velik-Salchner C, Haas T, Innerhofer P, Streif W, Nussbaumer W Klingler A, Klima G, Martinowitz U, Fries D: The effect of fibrinogen concentrate on thrombocytopenia. J Thromb Haemost 2007, 5:1019-1025.

6I. Ciavarella D, Reed RL, Counts RB, Baron L, Pavlin E, Heimbach DM, Carrico CJ: Clotting factor levels and the risk of diffuse microvascular bleeding in the massively transfused patient. $\mathrm{Br}$ Haematol 1987, 67:365-368.

62. Hiippala ST, Myllyla GJ, Vahtera EM: Hemostatic factors and replacement of major blood loss with plasma-poor red cell concentrates. Anesth Analg 1995, 81:360-365.

63. Mannucci PM, Federici $A B$, Sirchia G: Hemostasis testing during massive blood replacement. A study of 172 cases. Vox Sang 1982, 42: II3-123.

64. Gonzalez EA, Moore FA, Holcomb JB, Miller CC, Kozar RA, Todd SR, Cocanour CS, Balldin BC, McKinley BA: Fresh frozen plasma should be given earlier to patients requiring massive transfusion. J Trauma 2007, 62: I | 2-I I9.

65. Hess JR, Zimrin AB: Massive blood transfusion for trauma. Curr Opin Hematol 2005, 12:488-492.

66. Kashuk JL, Moore EE, Johnson JL, Haenel J, Wilson M, Moore JB, Cothren CC, Biffl WL, Banerjee A, Sauaia A: Postinjury life threatening coagulopathy: is $I: I$ fresh frozen plasma:packed red blood cells the answer? J Trauma 2008, 65:26I-270.

67. Kauvar DS, Holcomb JB, Norris GC, Hess JR: Fresh whole blood transfusion: a controversial military practice. J Trauma 2006, 6I:18I-184.

68. Ketchum L, Hess JR, Hiippala S: Indications for early fresh frozen plasma, cryoprecipitate, and platelet transfusion in trauma. J Trauma 2006, 60:S5I-58.

69. Malone DL, Hess JR, Fingerhut A: Massive transfusion practices around the globe and a suggestion for a common massive transfusion protocol. J Trauma 2006, 60:S9I-96.

70. Repine TB, Perkins JG, Kauvar DS, Blackborne L: The use of fresh whole blood in massive transfusion. J Trauma 2006, 60:S59-69.

7I. Sperry JL, Ochoa JB, Gunn SR, Alarcon LH, Minei JP, Cuschieri J, Rosengart MR, Maier RV, Billiar TR, Peitzman AB, Moore EE: An FFP:PRBC transfusion ratio $>I=I: I .5$ is associated with a lower risk of mortality after massive transfusion. I Trauma 2008, 65:986-993.

72. Stinger HK, Spinella PC, Perkins JG, Grathwohl KW, Salinas J, Martini WZ, Hess JR, Dubick MA, Simon CD, Beekley AC, et al.: The ratio of fibrinogen to red cells transfused affects survival in casualties receiving massive transfusions at an army combat support hospital. J Trauma 2008, 64:S79-85.

73. Bochicchio GV, Napolitano L, Joshi M, Bochicchio K, Meyer W, Scalea TM: Outcome analysis of blood product transfusion in trauma patients: a prospective, risk-adjusted study. World J Surg 2008, 32:2185-2189.

74. Scalea TM, Bochicchio KM, Lumpkins K, Hess JR, Dutton R, Pyle A, Bochicchio GV: Early aggressive use of fresh frozen plasma does not improve outcome in critically injured trauma patients. Ann Surg 2008, 248:578-584. 